\title{
A Critical Reappraisal of Pan-Africanism: A Quest for Supra- State Formation and Authentic Development in Africa
}

\author{
Thomas Adino Taye* \\ Addis Ababa University, Ethiopia.
}

*Corresponding Author: Thomas Adino Taye, PhD Candidate, Addis Ababa University, Ethiopia.

\begin{abstract}
The purpose of this study is three-fold. First, to rationally appraise the potential of a new and revised form of Pan-African Movement to constitute 'Supra-National Sovereignty'. Second, a critical attempt is made to examine the relevance of rethinking and rebranding the Pan-African Ideology for the existing economic crisis of Africa. Thirdly, to show the significance of Pan-Africanism as a panacea to block the neocolonial tendencies in contemporary Africa. I strongly believe that since the late 18th century to the mid20th century, Pan-African Nationalism has brought a dramatic change in the social, political and cultural life of African people as well as black Diasporas who were living abroad. Accordingly, some scholars argue that Pan-African Ideology had hugely assisted the African people to have political independence and national sovereignty. To the contrary, throughout the paper, I have argued that Pan-Africanism did not answer fully questions regarding continental unity and economic development. It is undeniable fact that Pan-Africanism had resolved the cultural and political questions of black people during the time of slavery and colonialism. However, the cultural, political, psychological, social, and scientific movement of Pan-Africanism was ceased and became stagnant since the 1960s without properly addressing the economic and governance problems of the continent. The post-independent African leaders did not completely eradicate the causes of mass poverty and mal-administration in their respective states by using the spirit of Pan-Africanism. They would rather leave aside Pan-African Ideology since the time of independence and they have been trying to realize the western origin political and economic ideologies such as; 'Marxism' and later 'Liberalism' via Structural Adjustment Programs (SAPs) and Poverty Reduction Strategy Papers (PRSPs). For me, this situation has created a widow of opportunity for westerners and other giant countries to a new scramble of Africa. In this phase of colonialism, the people of Africa will be detained both physically and mentally. These days, neo-colonial tendencies of the western and eastern world towards Africa becoming a fundamental threat to the survival of the continent and its people. Thus, I have proposed a neo-pan African nationalist movement in order to save our continent-Africa from endless exploitation, domination, segregation, and enslavement. Finally, in doing this research paper, scientific articles, books, electronic sources, conference papers, AU charters, government reports, and magazines have been used intensively to come up with concrete conclusion regarding the future fate of Africa.
\end{abstract}

Keywords: Neo Pan-Africanism, Negritude, African Nationalism, African Socialism, Supra-State, Regional Integration, and Neo-Colonialism

\section{INTRODUCTION}

As philosophy and ideology, pan-African nationalism incorporates the political, historical, cultural, spiritual, and scientific legacies of African people and the "diaspora". Pan-Africanism is also a cultural and political movement which promotes moral values, social norms, traditional principles, and customary laws that are the product of the ancient African civilizations. Moreover, pan-Africanism as a system has struggled against slavery, racism, colonialism, imperialism, and neocolonialism. Major actors of the Pan-African movement believed that the African people had brought peace and survived long until the coming of European colonizers by the help of these traditional moral values and customary laws.

In light of the above statements, we can deduced two major goals of pan-Africanism. The first is; to abolish slavery and colonialism by using Africanized ideology. The second one is; to realize the PanAfricanist dream of 'United States of Africa'. With the same token, Pan-Africanism has carried a mission of correcting the historical injustices of slavery, colonialism and racism. At the same time, Pan-Africanism also shouldered the goal of building a 'Supra-State Authority' by eliminating colonial and artificial boarders. To strengthen this assertion, Abdalla Bujra has proposed the following claim:

International Journal of Innovative Research in Electronics and Communications (IJIREC) Page | 34 
The Pan-African congress held in Manchester, in 1945, brought together African nationalist leaders from the diaspora and expressed Africa's vision in the following terms: (a) to achieve independence from colonial rule throughout the continent, so that Africans can rule themselves democratically, (b) to achieve continental unity so that Africa can (i) experience faster economic growth and catch up with the industrial countries, and (ii) assume strong position within the international system.

When we examine and assess the current situation of Africa, Pan-Africanism has achieved only its first goal i.e. political independence. However, Pan-African ideology was failed in achieving continental unity and economic development. The second and most important assignment of Pan- Africanism didn't accomplished and resolved by this nationalistic movement. Since 1960s, territorial conflicts among independent African states and economic crisis have been increasing in alarming pace. Since independence, the level and extent of poverty in Africa has been continuing.

Recently, the continent of Africa is synonymous with poverty, conflict, human trafficking, corruption, unemployment, xenophobia and the like. These worst situations of the continent have proved the fact that the earlier Pan-African movement did not go further in full filing its second objective i.e. unity and development in particular and in resolving the contemporary complications of the continent in general.

One of the central questions of this term paper is "how do we resolve the aforementioned problems of contemporary Africa? Since the last three decades, the majority of African states have been experiencing a multitude of political, social, and economic crisis. As a student of African studies, I have propose a revised and reorganized form of Pan-African ideology to curve these worst conditions across the land of Africa. Because, I strongly believe on the socio-political strategies and ideologies which are created by the general consent of Africa. For me, this may be the way out of Africa from contemporary problems. In line with this, the earlier pan-African nationalism was created by people of African descent and it was grounded on the powerful faith that continental unity is mandatory for economic development and neocolonial struggle.

The political history of Africa has shown as the fact that since the late 18th century to mid-20th century, the cultural and political ideology of pan-Africanism has improved the wrongs of slavery, racism, and colonialism. In the centuries mentioned above, people of Africa and black diaspora in America were considered as irrational, barbarian, primitive, half-devil and half-human, emotional, and the like by people of the western world. However, the struggle of African people under the motto and spirit of pan-Africanism has corrected these historical prejudices.

Accordingly, I have a faith in the recent wave of Pan-Africanism to block effectively the new scramble for Africa; to bring authentic development; and genuine continental unity. We can make Africa great again by the rational appraisal of pan-African ideology. Throughout the paper, I firmly argue that rebranding and rethinking pan-Africanism in a systematic way would have a potential to finish its former unfinished projects/programs such as: continental solidarity and development.

Now a days, scholars of African origin argue that 'Genuine Political Unity' among African sovereign states is the only survival and coping strategy from underdevelopment and neocolonialism. Political unity is the only instrument that we have to completely block and crash the new scramble of Africa by super powers. Hence, African nation-states should give up their national sovereignty and must cooperate one another to form a "Grand-Design of Federalism" with legitimate political authority and power. For this purpose, I have sated the following:

The fifty-three nation-states of the AU has come to realize over time the difficulties involving in building continental unity and development in an increasingly globalized world. Africa still contains some of the poorest countries in the world, with an average per capita income of just $\$ 600$ per year. It is also politically fractured and socially stratified in to rich and poor, literate and illiterate groups. It is further divided along religious lines- traditional religions, Christianity and Islam. These divisive political and social forces continue to chip away at Africa's fragile unity and development. However, some proponents of African unity, including the Libyan leader, Col. Muammar ai-Qadaffi, have called for the immediate creation of a formal federation dubbed a "United States of Africa" as the only way to fight poverty, ignorance and a myriad of other global challenges confronting the continent.

Therefore, as an African, we have to critically rebuild the ideology of pan-Africanism for the betterment of its people. It is obvious that the people of Africa have been leading the nastiest life since externals have reached the continent in the distant past. So, rebranding and reinitiating the ideal of 
pan-Africanism is not a luxury but a necessity and a matter of survival for the present and the coming generation of Africa. I think it is better to depict the following research outcome of Oyewole and Joash to support my line of argument:

African nationals are convinced that Pan-Africanism promotes Africa's shared values and identity. We conclude that pan-African ideology is changing with structural transformation inherent in the globalization process; therefore there is a need for the reconstruction and rebranding of the ideology in order to survive neocolonialism inherent in the capitalist slave-driven and exploitative corporate globalization being promoted in the 21 st century. Hence, African governments need to seize opportunity of the booming interned technology to promote the ideology of pan-Africanism from the grassroots to all levels of society.

Finally, I want to say something about the structure of my article. The paper is organized in to seven sections. The first section is the introductory part which deals about the different scholarly arguments regarding the issue of Pan-Africanism. The second topic focuses on the roots of Pan- Africanism. The third section emphasizes on the success and failure of Pan-Africanism. The fourth part mentions out the reasons behind the new wave of Pan-Africanism. Section five of the paper examines contemporary challenges of pan-Africanism. Part six of the paper puts valuable instruments which oil the progress of Neo Pan-Africanism. And, the final topic summarizes important points and provides crucial recommendations.

\section{ROOTS OF PAN-AFRICANISM}

Under this sub-topic, I will critically approach and sift-out questions such as: what does panAfricanism mean? Where and when pan-Africanism started? Who were the major actors of PanAfricanism? What are the conferences and major events of Pan-Africanism? Where is the break and continuity of Pan-African ideals? What is the current situation of Pan-Africanism?

The concept of pan-Africanism has been constantly used among African scholars, leaders, and political activists to portray condemnation against racism, enslavement, and colonialism. The term pan-Africanism has no single universally agreed definition. When we across different literatures regarding pan-Africanism, one can clearly access the various meanings and interpretations of panAfricanism which are imposed by researchers of the area. Accordingly, here after, I shall present the different but related meanings of pan-Africanism.

The African Union (AU) defined pan-Africanism as "an ideology and movement that encourages the solidarity of Africa's worldwide." Moreover, Oyewole and Joash viewed pan-Africanism from two main standpoints. First, they viewed it as an ideology that recognizes the African and Afro-American intellectuals and political activists as identical, and thus, it strengths racial solidarity based on a new self-consciousness. Second, they saw it as a movement that promotes political independence, racial equality, and continental unity. From these definitions one can simply deduced the assertion that success of African states in all affairs depend on continental unity and proper recognition of Africa's shared values, cultures, and beliefs. In other words, all African states should cooperate one another and voice together to alleviate their common problems such as: ethnic conflict, religious conflict, political instability, human trafficking, extreme poverty, unemployment, neocolonialism, corruption, violation of human rights and the like.

Moreover, the earliest concept of pan-Africanism has emphasized on the political and cultural unification among the people of Africa. To support this view, of pan-Africanism, Ofuatey Kodjoe has defined pan-Africanism as; "the acceptance of oneness of all people of African descent and the commitment to the betterment of all people of African descent."

Chrisman Robert also defines Pan-Africanism based on the core visions it had. For him, PanAfricanism is an instrument that mobilizes the people of African hereditary all over the world in order to build a common cultural, political and economic community by capitalizing the issue of racial discrimination, social segregation, economic exploitation, and denigration of self-rule. He also adds the point that unity of African people and the diaspora in all areas is an essential step and cornerstone for the dignity, liberation, equality, and development of the African nations and its people.

In the previous discussion, I have tried a lot to demonstrate the nature and meaning of panAfricanism. Now, I will go through with the other focus of this sub-topic i.e. the history and/or root of pan-Africanism. According to some writers, the history of pan-Africanism has rooted in the time of 
slave trade and survived actively till the 960s. The concept of pan-Africanism was originated by African descent in the diaspora, primarily from the Caribbean and United States of America. Some boldly say that pan-Africanism is a gift of black Diasporas in the Northern Hemisphere to African brothers and sisters. These Afro-American black Diasporas have started 'Pan-African Movement' as a response against the oppression and exploitation of the black men by a racist white people in the new world.

Racial injustice in the land of USA and the Caribbean has pushed and motivated black political activities and elites to address the structured and organized way of marginalization over the black people. This sense of shared struggle finally gave birth to a Pan-African movement and ideology in the Northern Hemisphere. That is why many scholars wrote without hesitate that pan- Africanism was not African in its origin and leadership. Furthermore, ownership of the Pan- African Movement and practice did not pass to Africans until the 5th pan-African conference. To substantiate this discourse, Micah S. Tsomondo portrays:

The concept of pan-Africanism has been around for a long time in spite of great historical events. Beginning as the nationalist thought of more or less detribalized Africans in the New World during the era of slavery, Pan-Africanism has survived the impact of such developments as the U.S. Civil War and Reconstructed, the Post-Reconstruction era, the rise and fall of the Garvey Movement, European colonialism in Africa, the Russian and other socialist revolutions of the twentieth century, and the black freedom movement in Africa, the United States, and the Caribbean since 1945.

When people discuss about pan-Africanism, it is mandatory to mention the big personalities and conferences that have contributed too much for Pan-African ideals. In this respect, the first panAfrican conference was held in London in 1900 and it was sponsored and organized by Henery Sylvester Williams-a Trinidadian who was working in London as a barrister. The conference was stayed for three days and participants from British Colonies, the UK, and the USA have addressed a number of issues regarding racial oppression and discrimination. Moreover, Marika Sherwood identified the major agendas of the 1900 Pan-African Conference as:

To secure civil and political rights for Africans and their descendants throughout the world; to encourage friendly relations between the Caucasian and African races; to encourage African people everywhere in educational, industrial, and commercial enterprise; to approach governments and influence legislation in the interest of black races; and to ameliorate the condition of the oppressed negro in all parts of the world.

The consequent five pan-African conferences (from the 2nd-6th) were organized and led by an AfroAmerican scholar-W.E.B DuBois. Chronologically, the 2nd pan-African congress was took place in Paris in 1919 which focused on racial segregation and marginalization. The 3rd congress was took part in 1921 (with three separate sessions- in London, Brussels, and Paris), the 4th pan-African conference held in 1923 (with two separate sessions- in London and Lisbon), the 5th pan-African conference gathered in 1927 in New York. These pan-African conferences (from 2nd to 5th) aimed the fight for racial discrimination, dignity of black people, and again intended to generate solutions for multidimensional problems of African descent.

According to scholars of the area, the 6th pan-African conference was conducted in Manchester in 1945. It was the most fundamental and significant event in which large number of African political leaders, activists, and scholars were represented and crucial decisions including a fight against European colonial rule were passed. The conference motivated Africans to fight against colonialism and it laid a foundation for political independence and self-rule. Africans believed that the 6th panAfrican conference has contributed a lot for the majority of African states to get their political liberation within and less than 20 years. In other words, African countries had breakdown the colonial yoke within a short period of time via the assistance of Pan-African ideology

Finally, I want to examine the contemporary situations of Pan-Africanism. Since the early 1970s, the emotion and commitment of African political leaders and activists towards the home grown ideology of pan-Africanism has been deteriorating. The post-independent African leaders have immediately forgot the role of pan-Africanism and they have started to look external (foreign) resources, ideologies, and policies for socio-economic development of their respective countries. However, these days, the majority of African countries despite the entitlement of relative political independence, they have been still suffering with corruption, mass poverty, devastating war, identity conflict, bad 
governance and the like. So, I believe on the critical reuse of pan-Africanism to crash out these problems from the land of Africa. In consistency of this claim, Ibraheem B. Sanusi summarizes the importance of a new wave of Pan-Africanism as:

Pan-African leaders have made conscious efforts to unite African people, in order to collectively deal with the multiple economic, social, and political challenges on the regional, national and global fronts facing the continent. Widespread poverty, devastating conflicts with attendant socio-economic ramifications, and numerous health issues, such as HIV/AIDS, malnutrition, malaria, high rate of infant mortality, and tuberculosis are to mention but a few some of the pressing contemporary challenges.

That is why I firmly argue for the revisiting of a recently forgotten Pan-African ideology in a way that eradicates our chronic contemporary glitches mentioned above.

\section{Examining The Success And FAILure of PAN-African Ideology}

Examining the success and failure of Pan-African movement and ideology is one of the tasks of my critical appraisal. One cannot firmly constitute a new wave of pan-Africanism without a rational assessment of its historical failures and successes. I argue that a continuing and problem solving panAfrican strategy should be established by logical dialogue and "communicative action" from a local (bottom) to state (top) level. Accordingly, the following major historical achievements and constraints of Pan-Africanism would help us to critically reframe and rebranding pan-Africanism for the purpose of improving and adjusting Africa's contemporary socio-economic ramifications.

It is better to start with the positive contributions and/or achievements of pan-Africanism. The first achievements of pan-Africanism was the abolishment of slavery in the Caribbean, USA, and Europe. It is obvious that the pan-African movement has contributed a lot to the emancipation of slave population in different corners of the world. So, one can confidently deduced the point that panAfricanism was served as an instrument to liberate people of African origin from the agony of slavery.

The second most important contribution of pan-Africanism was the creation of oneness and brotherhood among black African descent in and outside of the continent. In the history of mankind, I have learned the very fact that 'the difficult thing in the world is uniting people and the simplest thing is dividing people'. From this perspective, pan-Africanism did a huge achievement in the formation of sense of solidarity and shared identity among black African community.

The third victory of pan-Africanism was; it brings pro pan-African intellectuals to dig out our precolonial shared values and to produce an African political and economic ideology. That is why throughout all pan-African conferences, educated African citizens have conducted a number of researches that maximizes the dignity, equality, and freedom of black people. Hence, the pan- African struggle has produced elites, leaders, and activists who fight against slavery, racism, and colonialism.

The last but not the least triumph of pan-Africanism was; it makes free African nation-states from the hands of colonial rulers. In the 1960s, except few African countries, the majority of colonized states have got political independence because of pan-African sentiment. Scholars boldly wrote the significance of pan-Africanism in detaching African countries from European colonization and political dependency. Thus, the right of self-administration or self-rule without direct involvement of colonial masters has come to reality because of the struggle of African leaders, activists, peasants, workers and the like who have pan-African orientation.

Besides the aforesaid achievements, pan-Africanism has also consisted a number of weaknesses. The most quoted weakness of pan Africanism is; its failure to bring economic freedom inside the continent. One of the major objectives of pan-Africanism was to realize authentic development all over Africa. However, the people of the continent have still been experiencing starvation, extreme poverty, foreign aid, dependency, budget deficiency, famine, and the like. Based on this fact, I can framed the conclusion that pan-Africanism did not resolve the socio-economic evils of African people. Regarding this weakness of pan-Africanism, what Ljeoma symbolizes this as:

One major task that pan-Africanism set for itself-the complete liberation of the continent has been achieved, but the continent continues to be economically dependent on the west in particular, as well as, on other rich countries such as japan. Other emerging economic powers such as China and India have started creating some offshore wealth in many African countries. 
Accordingly, the question of authentic development has remained unsolved in the land of Africa. Furthermore, there are too much works expected from the new wave of pan-Africanism in improving the living standards of Africans.

Pan-Africanism had a task of uniting the people of Africa both politically and economically. However, pan-Africanism has failed in bringing the political unification as well as economic integration among nation states. The African Union is still struggling to bring greater continental integration and development because "one of the ultimate goals of Pan-Africanism is full political and economic integration leading to the United States of Africa". When we see the current situation of Africa, states are not politically united and economically integrated. One of the reasons that has frequently been mentioned by researchers concerning the disunity and disintegration of African nation-states is; "the pan-African agenda for 'African Unity', 'Progress', and 'Restoration' has been state-led".3 David Maimela further argues that:

There has been African cooperation, mostly at official state and economic sector level, but no real unity and integration has taken place yet in a manner that realizes the pan-African dream of one continent, one people, and one density.

From the above evidences, the researcher can draws a conclusion that the political ideology of panAfrican nationalism has failed when judged against the promises of United States of Africa.

The final limitation of pan-Africanism was; its deficiency towards well-articulated and rationally designed strategies and practices. In addition to this, pan-Africanism lacks a widely shared understanding of the needs of the African people from the grassroots level. Sanusi I.B., in his speech on the African Leadership Forum has declared:

It appears as if our founding fathers merely mouthed and parroted Pan-Africanism without contextually understanding its workability. In some cases, it was more of ego-tripping and black supremacy than putting superior ideas into action. In some unfavorable instances, it ended being peddled as an elitist agenda; a pet project of individual leaders who had personal motivations and agendas that is oft reduced to a perception of the OAU being merely a club of dictators and golf buddies.

The quotation entails the point that the earlier form of pan-Africanism lost momentum for lack of a clear direction ideology, and strategy. Many of the actors of pan-Africanism did not pit down precise statements regarding the leaderships and practical procedures to achieve the intended goals.

\section{REASONS TO RETHINK PAN-AFRICANISM IN TODAY'S AFRICA}

These days, scholars believe that rethinking pan-Africanism will provide numerous benefits to the continent of Africa and its people. They further argue that the only survival mechanism of the continent and its people is must be a careful implementation of neo pan-African ideology. The current global dynamics and world order enforces us to continually and critically appraise the achievements, limitations, and challenges that have tremendous impact on the success of pan- African projects and programs.

The central question regarding this issues is; why governments and peoples of Africa rethink and reimplement the new version of pan-Africanism? I argue that for three major reasons or inspirational forces, we have to rebranding and re-instigating the earlier pan-African movement in to a new sort of pan-Africanism with a refresh emotion and commitment. Hence, the reasons behind the need for panAfricanism in the contemporary Africa are three fold. These are; (i) to establish or constitute a suprastate authority; (ii) to successfully block neo-colonialism; and (iii) to assure authentic development in the land of Africa.

\section{Contemporary Challenges for the NeW WAVE OF PAN-Africanism}

To enjoy the fruits of pan-Africanism, one should clearly understand and overcome the challenges which affect the success of its goals. Meaning, identifying the whole challenges of Pan-African Projects and programs is, I believe, half of the solution to establish a supra-national sovereignty, to realize authentic development, and to block neo-colonialism. As I stated in the previous topic, the major objective of neo pan-Africanism should be the formation of genuine unity and shared cultural identity among the people of Africa. However, the earlier attempt to create a 'United Sates of Africa' was failed because of the following internal and external factors. 


\subsection{Geographical and Historical Challenges}

Africa is the second largest and the second most-populous continent, being behind Asia in both categories. The continent hosts a large diversity of ethnicities, languages, religions, political ideologies, historical backgrounds, resources and the like. Besides these differences, the states and peoples of Africa also share some common identities. For example, in the late 9th century, European countries colonized almost all of Africa except Ethiopia and Liberia, and most present nation states in Africa originated from a process of decolonization by using a pan-African weapon in the second half of 20th century. From this perspective, we can say that the newly independent African states have an identical experience of slavery, colonialism, imperialism, racism, and oppression. So, the geographical, demographic, and historical variations among African countries have negatively contribute for the establishment of 'Supra-National Sovereignty'. Paul G. Adogamhe persuasively states these challenges as:

The African continent is made up of several countries which differ significantly in size, demographic trends, levels of economic development, language, culture, societal norms, and natural resources endowment. Nigeria has the highest population density of about 40 million people, hundreds of times more than some small African countries. South Africa has the most developed economy with a capacity that is almost equal to that of forty other sub-Saharan countries combined, or one-third of the African continent. South Africa, Nigeria, Egypt and Algeria amount for half of the continent's GDP and nearly a third of its total population. Gabon has a very small population but large oil deposits, Botswana has diamond mines and a multiparty democracy, Sierra Leone and Liberia though impoverished because of years of civil war, have diamond mines. Therefore, any prospects for integration must not only take in to account the magnitude of all these societal and ecological disparities but also the African leaders' perceptions of these difficulties and their willingness to overcome them.

So, we have to develop the culture of accommodating these geographic, demographic, and economic disparities among African countries. Unless we compromise the natural and manmade inequalities among nation states, we will never achieve the major goals of pan-Africanism i.e. "Big State' formation. In this regard, I strongly recommend the new wave of pan-African activists and leaders should primarily work on connecting and uniting the people of Africa regardless of religion, ethnicity, language, color, level of economy, number of population, and area size.

\subsection{Security Challenges}

Africa is widely known by ethnic, religious, and boarder conflicts. Since independence, because of the planted legacy of colonialism and other related causes, many African countries have been living with endless wars and conflicts. Recently in Africa, we have been experiencing a number of chaos and/or disorder between ethnic groups of the same country or between states. Most of the time, confront zones in Africa have blocked the free entry of African immigrants who have passports of neighboring states. For me, the existence of this kind of reality in Africa seriously challenges the process of political integration in particular and supra-state formation in general. In a broad sense, the security challenges of Pan-African unity best explained in the note stated below:

To what extent is Africa prepared for a borderless continent, in which the African peoples can move freely without hindrance, including the right to permanent residence in countries other than their own? How can the African Union guarantee the right to free movement of persons in an atmosphere of xenophobia, given the ethnically and racially motivated violence in many parts of Africa? The chronic internal conflicts in Africa have resulted in vast population movement in and out of different national boundaries. Africa has the largest number of refuges and of internally displaced persons in the world. The treatment and intolerance of refuges in many African countries or events such as the deportation of Nigerians from Libya as economic migrants are not consistent with the calls for African solidarity or free labor migration.

Accordingly, it is expected from the new wave of pan-Africanism to eradicate the above security challenges to better realize the agenda of political and economic integration among members of the African Union. 
A Critical Reappraisal of Pan-Africanism: A Quest for Supra-State Formation and Authentic Development in Africa

\subsection{Political and Leadership Challenges}

For me, political power in Africa is the matter of life and death. The post-independent political history of Africa has shown us, the majority of state leaders have gained political power via armed struggle and similarly lost their power through military force or coup d'état. That is why democratic election in Africa marked by widespread rigging, fraud, post-election violence and conflict. Based on this lively reality of the continent, how African leaders simply give up their sovereign power to a certain SupraInstitution? So, the undemocratic nature of rulers and their strong affection of political power might weaken the Neo Pan-African struggle to wards voluntary federation of African countries. I took the following script to strengthen my argument:

One important lesson of regional integration theory, which draws on the success of the European Union, is that the existence of elites with a shared commitment to democracy as the foundation of long-term economic cooperation and development. But unfortunately the African elites have fallen short of offering any such meaningful economic and political ideological consensus that is capable of transforming the continent in to a modern democratic supra-state.

It is the ubiquitous fact that a successful political and economic integration among countries and peoples of a specific continent or block will depend on the nature and behavior of political actors and elites. Except few, the majority of African political leaders do not have shared commitment to rule of law, transparency, accountability, universal suffrage, popular sovereignty, tolerance, peaceful transition of political power and so on as the foundation of 'United Sates of Africa'. Most of the time, political leaders under the umbrella of African Union have refused to adopt a legal charter and/or democratic document that would have a mandate to avoid unpopular and predatory presidents. Thus, the present pan-African movement should strive on the building of democratic values and principles in the land of Africa. Because, it is unthinkable to attain continent wide political and economic integration without fair and transparent systems.

\subsection{Economic Challenges}

Africa is one of the least continents in terms of basic societal infrastructures such as inter-state asphalt roads, rail ways, electrifications, clean water supplies, and the like. The continent has no financial capacity to build infrastructures which fasten the economic integration process. For me, the major concern of Final Act of Lagos (1980) i.e. achieving free trade and common market in Africa will not be successful without the infrastructures mentioned above. Still there is no tangible infrastructure which connects African states from the north to the south and from the east to the West Africa. For your surprise, in the age of globalization, almost all African people living inside the colonial and dictatorial building boxes. They are prisoners of specified territory either by lack of visionary political leaders or by lack of adequate infrastructures. For example, because of conflict of interests between two predatory leaders (the late Prime Minister of Ethiopia-Meles Zenawi and Esayas Afeworki), the people of Ethiopia and Eritrea have stopped any sort of interaction for the last 20 and more years.

In light of the previous assertion, the creation of continental solidarity and territorial integrity among African counties and peoples need the existence of adequate infrastructures. And, infrastructures in all areas would positively contribute for inter-state trade and cooperation. Regarding economic challenges of pan-Africanism Abdalla Bjura argues that:

without economic cooperation and eventual integration of the generally small national economies of Africa, it would be impossible to achieve any meaningful alternative development as a way out of the crisis. More importantly, without such cooperation and integration, Africa will not be strong enough to bring about any change, however small, in the existing international economic order. And such a change was crucial if Africa was to have any meaningful space to embark on an alternative form of development and overcome its crisis.

\subsection{Global Challenges}

Besides internal challenges of pan-Africanism, the hands of externals have played a significant role for the failure of pan-African projects and programs. It is obvious that former colonizes have provide financial assistance to disintegrate Africa for the purpose of decolonization. Since political independence till now, European countries have been trying a lot to weaken and exploit African states. Westerners have a hidden political and economic strategies to Balkanize and control the economy African states. A simple illustration for this claim has presented by Ljeoma as:

International Journal of Innovative Research in Electronics and Communications (IJIREC) Page | 41 
Both the African Union and New Partnership for Africa's Development (NEPAD) were born at times of the greatest external control of African economies by outsiders than at any time since independence. This was a period after two lost decades during which many African countries were subjected to economic reforms guided by the Washington Consensus. Today, there is a heightened tension between the assertions of collective self-reliance and the appeals for financial dependence. NEPAD is quite unusual in that there has been extraordinary interest on the part of many non-African actors.

In a nut shell, the pan-African actors should struggle a lot to curve the geographical, historical, political, leadership, economic, security and global challenges and finally to objectively realize their dream of "Supra-National Authority" and authentic development to end the agony Africa.

\section{Mechanisms to Oil the New Form of PAN-AfRiCAnism}

As a scholar, it is mandatory to suggest some basic solutions for the problems of pan-Africanism. In the previous topic, I have discussed the major challenges that negatively affect the progress of panAfrican programs and projects. Pan-African activists cannot easily eradicate the challenges mentioned above without proper and indigenous tactics developed by the consensus of African people. Hence, in the following paragraphs, I will indicate some appropriate mechanisms which truly help Africans to communicate about the ideals and symbolize the ultimate aims of 'Neo Pan- Africanism' in the land of Africa.

Regional peace and security are essential to actualize the objectives of 'Neo Pan-Africanism' i.e. grand design of federalism, authentic development, and self-reliance. Without these ingratiates (peace and security) the present efforts and energies exerted by African Union, Pan-African activist, and other sections of a certain community are wasted. Thus, there must be peace and security when we across African states to seedling down and portray the integration project of Pan- Africanism. A scholar-Paul G. Adogamhe argues for this claim as:

The ideals of pan-Africanism cannot be achieved without serious commitment to conflict resolution, peace building, public accountability, and the consolidation of democracy throughout the continent. The real challenge before the African leaders as they revisit Pan-Africanism as a blueprint for African unity and development is whether they have the political will and exceptional leadership skill to rekindle such a strategic vision that will unite and transform the continent in to an integrated, stable, democratic and prosperous society. That task is more urgent today than at any time in Africa's postcolonial history, given the imperatives of socio-economic and political challenges confronting the continent.

The second mechanism that oils the process of making 'Grand Federalism' and 'Authentic Development' is the advancement of home-grown solutions for our political, economic, social, cultural, technological and other problems. With the same token, we have to stop blind acceptance of western policy frameworks as well as complete dependency on imported legacies to ameliorate the worst conditions of our people. The non-indigenous socio-political instruments didn't minimize the complications and difficulties that we Africans facing in various circumstances. Rather these borrowed blueprints have been aggravating the level of poverty, conflict and unemployment across many African countries. Therefore, the future Pan-African movement should struggle massively to generate an African political and economic ideology such as; black capitalism, black liberalism, black socialism and the like which are really emanated from the history and culture of the continent. Sanusi powerfully describes this mechanism as:

A skillful combination of ingenious and modern knowledge system, African countries could devise well thought-out and creative strategies for the transformation of their social structures, political systems, and economic organizations to the present world environment, so that the continent as a whole would successfully claim the 2 st century.

Searching our shared cultural values and accepting our diversities are the other tactics which aids the fight of Neo Pan-Africanism over mass poverty, unemployment, inter-state conflict, and disunity in the entire continent. I enormously argue that the similarity among African people is greater than their difference. For the purpose of successful integration, the people of Africa should re-appropriate on their shared cultural norms. A careful cultivation of our common identities and shared values in the minds of African children will ultimately fulfil our dream of 'United states of Africa'. 
Conducting successive continental-wide discourse among Africans regardless of political power, race, sex, age, language, religion and class might be the other approach which facilitates the renaissance of Africa. Organizing continual conferences on the future fate of Africa (like previous Pan-African conferences), will maximizes the interaction and exchange of cultures and ideas among Africans. In addition to fixed conference schedules, we have to share ideas through social and other media to save the continent of Africa from the current trend of neocolonialism. The subsequent point has convinced me concerning this instrument of pan-Africanism:

African young people have also been at the forefront, forging continental unity through cross boarder travel and social media. In this digital era, social media has turned in to a popular platform to interact and engage in debates. For instance, as South Sudan recently plunged into political in-fighting and the Central African Republic was on the brink of a religious conflict, twitter hash tags and Facebook posts were used to convey messages of peace. On Facebook alone there are hundreds of Pan-African groups. Some are popular with thousands of members; such as the "Pan-African Network", "PanAfrican Movement Reborn", "Pan- African fundamentalism", "Being Pan-African", "Center of PanAfrican Culture" etc.

I certainly believe on the statement that wise use of internet and social media would positively contribute for the free flow of ideas and information from one place to the other. We can preach the ultimate objectives of Pan-Africanism via social media. By using social media, we can also mobilize the vast human and material resources to put the foundation of real African Unity and development. Moreover, one can also easily disseminate creative strategies, good practices, conference reports, technological innovations, and our shared values by the help of internet applications all over Africa within a fraction of seconds. Thus, we Africans can communicate one another and prepare conducive environment for regional integration by wise use of media.

\section{CONCLUding REMARKS}

Pan-Africanism is both an ideology and movement that encourages the solidarity and oneness of African descent in and out of the continent. As a movement and ideology, pan-African nationalism incorporated the political, historical, cultural, spiritual, and scientific legacies of African people and the diaspora. The pan-African movement was aimed on the promotion of moral values, social norms, traditional principles, and customary laws that are the product of ancient African civilizations. Moreover, pan-Africanism as a system has struggled against slavery, racism, colonialism and/or imperialism. Meaning, Pan-African nationalism has carried a mission of correcting the historical injustices of slavery, colonialism and racism. Therefore, from these features of pan-Africanism, we can scrutinized the following two major objectives: (i) Pan- Africanism can be viewed as an ideology that recognizes the African and Afro-American intellectuals and political activists as identical, and thus, it strengths racial solidarity based on a new self-consciousness. (ii) Pan-Africanism is a movement that promotes political independence, racial equality, and continental unity.

In line with the earlier objectives of pan-Africanism, the paper intensively discussed on the achieved and failed aims of the project. Accordingly, some of the major achievements of pan- Africanism are: (i) It played a lot for the abolishment of slavery in the Caribbean, USA, and Europe. It is obvious that the pan-African movement had an immense contribution for the emancipation of African slave population in different corners of the world. (ii) It played well for the creation of sense of oneness and brotherhood among black African descent in and outside of the continent. (iii) It brought pro panAfrican intellectuals to dig out our pre-colonial shared values and to produce an African political and economic ideology. (iv) It did a lot in making too many African states free from the hands of colonial rulers. As a result, in the year 1960s, except few African countries, the majority of colonized states have got political independence because of pan- African struggle.

Besides the achievements of Pan-Africanism, the paper also identified some of its weaknesses. One of the major shortcomings of Pan-Africanism is its failure in bringing economic freedom inside the continent. That is why the people of Africa have still been experiencing starvation, extreme poverty, foreign aid, dependency, budget deficiency, famine, and the like. The second drawbacks of panAfricanism is its failure in realizing the political unification as well as economic integration among African states. The last but not the least limitation of pan-Africanism is its deficiency towards wellarticulated and rationally designed strategies and practices which emanate from the general public. 
A Critical Reappraisal of Pan-Africanism: A Quest for Supra-State Formation and Authentic Development in Africa

Meaning, pan-Africanism lacks a widely shared understanding of the needs of the African people from the grassroots level.

A complete avoidance of the shortcomings mentioned above would help Africans to simply accomplish the remaining tasks (i.e. to constitute a supra-state authority; to successfully block neocolonialism; and to assure authentic development in the land of Africa) of Pan-Africanism. However, there are a number of internal and external factors (geographical and historical, security, political, leadership, economic, and global) which have been affecting the proper implementation of the new wave of pan-Africanism. So, the new wave of a pan-African movement should address these challenges for the purpose of African renaissance.

Finally, the researcher has suggested various coping strategies which activate the neo pan-African movement. Accordingly, assuring regional peace and security, promoting home-grown solutions, searching a shared African cultural values, accepting our diversities, educating the youth and community, conducting successive continental-wide discourse among Africans, advancing a systematic use of the new media are the major strategies which galvanize the realization of panAfrican programs and projects in the near future.

\section{REFERENCES}

[1] Abegunrin, O. (2009). Africa in Global Politics in the Twenty-First century: A Pan-African Perspective. New York: Palgrave Macmillan Press.

[2] Adogamhe, P. G. (2008, July). Pan-Africanism Revisited: Vision and Reality of African Unity and Development. African Review of Integration, 2, -34.

[3] Ake, C. (965). Pan-Africanism and African Governments. Review of Politics Journal , 532-542.

[4] Brimingham, D. (995). Introductions to History: The Decolonization of Africa. Gower Street-London: UCL Press Limited .

[5] Bujra, A. (2004). Pan-African Political and Economic Visions of Development: From the OAU to the AU, and From the LagosPlan of Action (LPA) to New Partner for African Developemnt (NEPAD). Development Policy Management Fourum (pp. -34). Addis Ababa: United Nations Economic Commision for Africa.

[6] Chrisman, R. (973). Aspects of Pan-Africanism. Black Scholar, 4, 2-5.

[7] Eze, M. O. (203). Pan-Africanism: A Brief Intellectual History. Journal of History Compass, 633-674.

[8] Galafa, B. (2008, October). Negritude in Anti-Colonial African Literature Discourse. Africology: Journal of pan-African Studies, 2, 287-299.

[9] Hakim Adi, a. M. (2003). Pan-African History: Political Figures from Africa and the Diaspora since 787. London and New York: Routledge: Taylor and Francis Group.

[10] Isfahani, A. (2008). White Negritude: Race, Writing and Brazilian Cultural Identity. 75 5th Avenue-New York: Palgrave Macmillan Press.

[11] J.Coleman, e. (965). Pan-africanism or Nationalism? In: Mc Ewan, Peter J.M, and Robert B. eds: The Study of Africa. London: Methuen Co.Ltd.

[12] Jacques, F. (200). Philosophy in Black: African Philosophy as Negritude. The 7th Congress of African Studies, 1 -17.

[13] John.K, M. (998). African People in the Global Village: An Introduction to Pan-African Studies . New York : University Press of America .

[14] Johnson, R. (200). Fighting for Africa: The Pan African Contributions of Ambassador Dudley J.Thompson and Bill Sutherland. Maryland: University Press of America.

[15] Kanneh, K. (998). African Identities: Race, Nation, and Culture in Ethnography, Pan-Africanism, and Black Literatures. London and New York: Routledge: Taylor and Francis Group .

[16] Kanu, A. (203). Nkrumah and the Quest for African Unity. American International Journal of Contemporary Research, 110-114.

[17] Legum, C. (965). Pan-Africanism: Ashort Political Guide . New York, Wshington, and London: Fredrick A. Praeger Publisher.

[18] Ljeoma. (2008). Rethinking Pan-Africanism: Dilemmas and Efforts towards African Integration . Journal of African Studies, 1-24.

[19] Maimela, D. (203). Pan-Africanism of the 2st Century: Challenges and Prospects. The Journal of Helen Suzman Foundation, 34-39.

International Journal of Innovative Research in Electronics and Communications (IJIREC)

Page $\mid 44$ 
A Critical Reappraisal of Pan-Africanism: A Quest for Supra-State Formation and Authentic Development in Africa

[20] Mark Malisa, a. P. (208). Pan-Africanism: A Quest for Liberation and the Pursuit of a United Africa. Journal of Genealogy , 1- 15.

[21] Moller, B. (200). Pan-Africanism and Federalism. Journal of Federal Studies , 38-76.

[22] Nardal, P. (2009). Beyond Negritude: Essays from Woman in the City. Albany : State University of New York Press.

[23] Nnuriam, P. (208). The Influence of Pan Africanism on Africa's International Relations. Equatorial Journal of History and International Relations, 13-21.

[24] Nurse Derek, a. S. (985). The Swahlli: Reconstructing the History and language of an African Society, 800-500 Ethnohistory. Pennsylvania: University of pennsylvania Press .

[25] O.A. Sylvester, a. O. (204). Decolonizatiin in Africa and Pan-Africanism . Journal of Philosophy and Religious Studies, 7-31.

[26] Ofuatey-Kodjoe. (986). Pan-Africanism: New Direction in Strategy. Lanham, MD: University Press of America .

[27] Oyewole Simon Oginni, a. J. (206, March). African Renaissance and Pan-Africanism, A Shared Value and Identity among African Nationals. Africology: the Journal of Pan-African Studies, 9, 39-58.

[28] Pardos, A. (206). Pan-Africanism and the Road to an African Renaissance . Journal of AP Comparative Government and Politics, 2-9.

[29] Pardy, H. (967). W.E.B Du Bois and Pan-Africanism: His Place in its Early Development. HamlitonOntario, Mc Master University, Department of Political Science, 1-92.

[30] Poe, D. (2003). Kwame Nkrumah's Contribution to Pan-Africanism: An Afrocentric Analysis. New York: Routladge:Taylor and Francis Group.

[31] Potekhin, I. (970). Pan-Africanism and the Struggle of the Two Ideologies . The Soviet Journal of Communist , 36-48.

[32] Ratcliff, A. J. (2009). Libration at the End of Pen: Wrting Pan-African Politics of Cultural Struggle. University of Massachusetts, Department of Afro-American Studies , 1-304.

[33] Sanusi, I. B. (203). Pan-Africanism: It's about African Shared Values . Africa Leadership Forum (pp. -4). Ota: African Union (AU) .

[34] Schramm, K. (2000). African Homecoming: Pan-African Ideology and Contested heritage. Walnut CreekCalifornia : Left Coast Press Inc. .

[35] Shepperson, G. (962). Pan-Africanism and "Pan-Africanism": Some Historical Notes. Journal of Phylon, 346-358.

[36] Sherwood, M. (202, January). Pan-African Conferences 900-953: What Did 'Pan-Africanism' Mean? Journal of Pan-African Studies, 4, 106-126.

[37] Snail, M. (2008). The Balck Conciousness Movement in South Africa: A Product of the Entire Black World . Journal of HAOL, 51-68.

[38] Thomas, G. (2007). The Sexual Demon of Colonial Power: Pan-African Embodiment and Erotic Schemes of Empire. Bloomington and Indianapolis: Indiana University Press.

[39] Tsomondo, M. S. (975). From Pan-Africanism to Socialism: The Modenaization of an African Liberation Ideology. A Journal of Opinion, 5, 39-46.

[40] Walker, R. (2009). Monopoly Capital and Pan-Africanism . London : cambridge University Press

Citation: Thomas Adino Taye, "A Critical Reappraisal of Pan-Africanism: A Quest for Supra-State Formation and Authentic Development in Africa." International Journal of Innovative Research in Electronics and Communications (IJIREC), 6(4), pp.34-45. http://dx .doi.org /10.20431/2349-4050.0604004

Copyright: (C) 2019 Authors this is an open-access article distributed under the terms of the Creative Commons Attribution License, which permits unrestricted use, distribution, and reproduction in any medium, provided the original author and source are credited. 